\title{
Rivalernes forår i Yemen
}

\section{Siris Hartkorn}

\section{Yemens variant af det arabiske forår er et klude- tæppe af aktører, fra præsidentens gamle rivaler over rebeller i nord og syd til stammeledere, traditionelle oppositionspartier og unge demon- stranter}

Få minutter efter at Hosni Mubaraks afgang blev annonceret på de internationale tv-stationer, blev der ringet fra den yemenitiske præsident Ali Abdullah Salehs kontor til flere sheiker fra Yemens mest magtfulde stammer. Beskeden fra præsidenten var kort og klar: regeringen havde stillet telte op på Sana'as Tahrirplads, og nu forventedes stammelederne at mobilisere deres stammer fra landsbyerne og indtage pladsen, før oppositionen fik mulighed for det.

De følgende måneder tilbragte regeringsloyale stammefolk med at tygge khat, spise og sove på Tahrirpladsen, mens unge organiserede protester ved Sana'a Universitet. Alligevel blev det regimet, der tabte spillet om symbolerne, for mens de i første omgang sikrede sig Tahrirpladsen, så begyndte der pludselig at dukke 'Forandringspladser' op i alle byer i Yemen, og det arabiske forår blev det manuskript, som alle spillere i kampen om Yemens fremtid måtte holde sig til.

Inspireret af begivenhederne i den arabiske verden startede veluddannede unge fra Sana'a universitet det, der fra starten lignede en umulig mission. Ingen troede for alvor på, at en gruppe idealistiske studerende ville nå langt i et land, hvor stammeloyaliteter og religion er vigtigere end politik, og hvor størstedelen af befolkningen, der i øvrigt er bevæbnet, tilbringer op mod seks timer dagligt med at tygge khat.

At det alligevel lykkedes de unge at skabe momentum for en fredelig revolution skyldes, at de blev den samlende kraft, der kunne forene alle regimets modstandere $i$ en bred anti-Saleh koalition. Koalitionen har stået samlet i kravet om Salehs afgang, men rummer samtidig store 
interne modsætninger og forskellige politiske dagsordener. Mens de unge er drevet af ønsket om demokratiske reformer, er der helt andre interesser på spil for de resterende aktører. Dermed står konflikten ikke alene mellem en autokratisk regering og en reformkrævende befolkning, men er en kompleks mosaik af skiftende stammealliancer, gamle rivaler fra de magtfulde familier, militante islamister, oprørere i syd, rebeller i nord, et splittet militærapparat og en politisk opposition, der mangler legitimitet på gaden. Alt sammen orkestreret af folkelige protester i hele landet. Læg dertil de to henholdsvis regionale og globale stormagter, Saudi-Arabien og USA, og deres indblanding i konflikten samt en økonomi, der med faretruende fart nærmer sig bankerot.

\section{Gamle rivaler}

At få Saleh fjernet fra posten som præsident er kun den første styrkeprøve. Den store udfordring bliver at forene de forskellige interesser i koalitionen og skabe opbakning til en plan for et samlet Yemen post Saleh.

For at forstå, hvilken form det arabiske forår har taget i Yemen, og hvilke udfordringer landet nu står overfor, er det derfor nødvendigt at gå bagom manuskriptet og i stedet se på de forskellige lag i konflikten og de aktører, der nu kæmper om landets fremtid.
Kernen i konfliken i Yemen er en politisk magtkamp mellem gamle rivaler inden for præsident Salehs egen stamme og stammeføderation. Den magtkamp har rødder langt tilbage i tiden, men det er først i de seneste år, den er udspillet i fuld offentlighed.

Da Saleh i 1978 kom til magten i Yemen, var det med hjælp fra hans stamme Sanhan, og særligt Ali Mohsin spillede en central rolle. Ali Mohsin står over Saleh i Sanhans interne stammehierarki, og det er en udbredt opfattelse, at han overlod præsidentposten til Saleh i forvisning om, at han ikke ville holde længe - Salehs to forgængere var inden for ni måneder begge blevet dræbt $\mathrm{i}$ attentater. Der blev internt i Sanhan indgået en aftale om, at hele stammen bakkede op om Saleh som præsident, men at Ali Mohsin ville blive hans efterfølger. I mere end tyve år fungerede aftalen fint, men ved årtusindeskiftet begyndte Saleh at lægge op til, at hans ældste søn, Ahmed, skulle efterfølge ham.

Det ledte til en splittelse i Sanhan, som primært har udspillet sig bag den politiske scene, men dog også fik en afgørende rolle i Houthi-konflikten, der startede i 2004. I Yemen er det en offentlig hemmelighed, at Saleh og hans nærmeste folk i regimets inderkreds ad bagveje forsynede Houthierne med våben og gav Saudi-Arabien koordinater på bombemål, som senere viste sig at være hærens 1 . divisions positioner. 
Disse ufine metoder tjente formålet at underminere Ali Mohsin, General og leder af 1 . division, og få ham til at fremstå som svag i kampen mod Houthi-rebellerne. Det var hensigten, at Ahmed Saleh, præsidentens søn og leder af den Republikanske Garde, skulle komme Ali Mohsin til undsætning, besejre Houthierne og fremstå som krigens sejrherre for at positionere ham som egnet efterfølger til sin far.

Det var derfor ikke nogen pludselig indskydelse eller overbevisning om demokratiets fortræffeligheder, der 21. marts i år fik Ali Mohsin til at skifte side til de unge demonstranter og tage hærens 1 . division med sig. Dette er heller ikke nødvendigvis et udtryk for, at Ali Mohsin fortsat ønsker at overtage posten som præsident, men skal i lige så høj grad ses som hans forsøg på at redde sig selv og Sanhan fra at ryge med i Salehs fald.

\section{Salehs stammebagland}

Det er ikke kun udfordringen fra Ali Mohsin, som Saleh har måttet håndtere i forhold til sit stammebagland. Sanhan hører under Yemens mest magtfulde stammeføderation, om end ikke den største, Hashid. Frem til sin død i 2007 var Sheikh Abdullah al-Ahmar leder af Hashid og grundlægger af Yemens største oppositionsparti al-Islah samt nær allieret med Saudi-Arabien. Abdullah alAhmar bakkede udadtil op om præ- sident Saleh i en særegen magtfordeling, der sikrede al-Ahmar posten som parlamentsformand. Efter alAhmars død blev den ene af hans ti sønner, Sadiq al-Ahmar, leder af Hashid, mens en anden søn, Hamid al-Ahmar, har overtaget lederskabet af Islah.

Hamid al-Ahmar har længe været en kendt figur i Yemen, hvor han har skabt sig en karriere som karismatisk politiker og medlem af parlamentet siden 1993, succesfuld forretningsmand og tæt knyttet til sin stammebaggrund.

Mens Saleh og Abdullah al-Ahmar kunne enes om en magtfordeling, har deres sønner lagt op til et opgør i kampen om magten. Hamid alAhmar og Ahmed Saleh har længe stået øverst på listen som præsidentkandidater, og siden valget i 2006 har Hamid al-Ahmar åbent kritiseret Saleh og dennes familie. At Hamid al-Ahmar og oppositionen stillede sig på de unge demonstranteres side, er derfor ikke overraskende, men Sadiq al-Ahmar tøvede, inden han også officielt vendte præsidenten ryggen og efterlod denne med stækket opbakning i sit eget stammebagland. Det er denne magtkamp, der resulterede i de voldsomme kampe i Sana'a i slutningen af maj, og den vil også i fremtiden spille en afgørende rolle i Yemen.

Stammerne er centrale aktører i Yemens politiske mosaik, men der er også andre vigtige aktører, der i årevis har formet konfliktlandskabet og 
vil få stor indflydelse på Yemens fremtid som et samlet land. Det gælder især Houthi-rebellerne nord for hovedstaden i grænselandet til Saudi-Arabien, og løsrivelsesbevægelsen i det tidligere Sydyemen.

\section{Rebeller i nord og syd}

Regeringen har siden 2004 forsøgt at nedkæmpe Houthi-rebellerne, en konflikt der startede som en lokal religiøs disput, men som udviklede sig til krig i seks runder med omkring 10.000 dødsofre og 250.000 internt fordrevne. Konflikten i sig selv er som alt andet i Yemen mere kompleks end som så, men skal ikke $g \varnothing-$ res til emne for en længere udredning her.

På trods af våbenhvile siden 2010 er konflikten aldrig blevet løst og Houthi-rebellerne har under den nuværende politiske turmult spredt deres indflydelse til grænseprovinser. At konflikten har været så langtrukken, kan til dels tilskrives den føromtalte taktik, Saleh benyttede sig af for at underminere Ali Mohsin. Men Houthi-rebellerne vidner også om, hvor stærkt og ikke mindst bevæbnet det yemenitiske samfund er. For mens det ikke var meningen, at Houthi-rebellerne skulle besejres af Ali Mohsin under de første fem runder, så var det absolut hensigten under den sjette runde, hvor både den Republikanske Garde og Saudi-Arabien blev inddraget for at knuse rebellerne.
Men de holdt stand og er stadig en indflydelsesrig aktør i Yemens nordlige provinser.

I det tidligere Sydyemen har en oprørsbevægelse, Al Hirak, siden 2007 protesteret mod regimet. Efter foreningen mellem Syd- og Nordyemen i 1990 udbrød der politisk uenighed mellem de to tidligere regeringer, hvilket i 1994 resulterede i en borgerkrig, hvor Saleh og det tidligere Nordyemen vandt. Siden har der i syd været en udbredt følelse af politisk og økonomisk diskriminering, og i 2007 udmundede dette i demonstrationer.

Saleh slog fra starten hårdt ned mod demonstrationerne i et mislykket forsøg på at nedkæmpe den største potentielle udfordring for statens legitimitet: Yemens enhed. Protesterne voksede i syd, nu foranlediget af regeringens vold, og bevægelsen udvikledes fra krav om økonomisk og politisk ligestilling med nord til krav om løsrivelse og selvstændighed. Bevægelsen omfatter både socialister, militante islamister, stammer, pensionerede militærfolk og almindelige borgere uden en fælles plan for Sydyemen, hvis løsrivelse skulle blive en realitet.

At de unge kunne sprede deres protester til byer i hele landet, inklusiv Aden og Sada'a, skyldes i høj grad, at Houthi-rebellerne og Al Hirak bakkede op om kravet om Salehs afgang. Men det er også med involveringen af disse to aktører, at de interne modsætninger i koalitio- 
nen mod Saleh har vist sig. For mens både Al Hirak og Houthi-rebellernes fjendtlige indstilling til Salehs styre har været en central drivkraft i de to konflikter, er hans afgang ikke nok til at løse dem. Og hverken Ali Mohsin, skulle han gå efter præsidentposten, eller Hamid al-Ahmar har opbakning hos de to aktører. Ali Mohsin har spillet en fremtrædende rolle i regeringens militære offensiver både under borgerkrigen mod syd i 1994 og i Houthi-konflikten. Hamid al-Ahmar har også spillet en central rolle i krigen mod Houthirebellerne og grundet sin stammebaggrund bliver Hamid al-Ahmar i syd betragtet som en variant af det gamle styre.

\section{Al-Qaeda og de store}

Yemenitterne har stået over for kriser før og har ved hjælp af et stærkt civilsamfund, humor og politisk debat bevaret troen på fremtiden, også når den så mest sort ud. Det samme gælder i den nuværende krise, hvor mange yemenitter til trods for den kritiske situation tror på bedre tider. Det skyldes håbet om en politisk elite, som vil prioritere Yemens økonomiske udfordringer, i modsætning til det nuværende styre, der i høj grad har valgt kortsigtede løsninger med egen overlevelse for øje.

Men her opstår der en interessekonflikt, for det er ikke alene op til interne aktører at afgøre fremtiden. USA og Saudi-Arabien spiller en vig- tig rolle i Yemen, og de er begge drevet af en snæver sikkerhedsinteresse, der ikke nødvendigvis er forenelig med store politiske forandringer.

USA og Saudi-Arabien har længe set Saleh som deres allierede i kampen mod al-Qaeda på den Arabiske Halvø (AQAP) og garant for nogenlunde stabilitet i Yemen. Mens begge lande nu har indset, at Saleh har udspillet sin rolle og udgør en trussel for stabiliteten i landet, så mener de stadig, at det gamle politiske system skal bevares, blot med en mindre kontroversiel erstatning for Saleh. Saudi-Arabien har altid spillet en dobbeltrolle i Yemen, på den ene side ved at støtte landet, så det ikke kollapsede, men samtidig holde det nede, så det ikke voksede sig til en potentiel trussel mod Saudi-Arabiens hegemoni på den Arabiske Halvø. Saudi-Arabien spillede en central rolle i likvideringen af daværende præsident Ibrahim al-Hamdi i 1977, der havde startet et ambitiøst økonomisk reformprogram og stækket stammernes, og dermed SaudiArabiens uofficielle magt. Det er bare et af mange eksempler på Saudi-Arabiens indblanding i Yemen med egne interesser for øje, og med generationsskifte i Riyadh er dets politik ikke blevet mere gennemskuelig.

Dog står det klart, at Saudi-Arabiens Yemen-politik er drevet af sikkerhedspolitiske interesser, herunder at begrænse Houthi-oprøret i 
Sada'a og bekæmpe al-Qaeda, men landet står dog også i et dilemma i forhold til håndteringen af Saleh. I skrivende stund befinder Saleh sig på et hospital i Saudi-Arabien, der nødig ser Saleh vende hjem til Yemen. Men i forsøget på at nedkæmpe tilløb til et arabisk forår på hjemmebanen og i Bahrain, ville det ikke se godt ud, hvis Saudi-Arabien spillede en aktiv rolle i en arabisk leders fald efter pres fra folkelige protester i nabolandet. Lykkes det Saudi-Arabien at forhindre Saleh i at vende tilbage, vil en ny politisk orden i Yemen ikke kunne overleve uden støtte fra Riyadh.

USA's politik i Yemen er drevet af kampen mod terror, særligt al-Qaeda, og USA's økonomiske bistand til Yemen har de seneste ti år også fulgt proportionelt med truslen fra alQaeda. Af samme grund har det været i Salehs interesse at overdrive truslen fra al-Qaeda, der har sikret ham amerikansk støtte. Det er primært i de sydlige og østlige provinser, at al-Qaeda er tilstede, men ofte tillægges de aktiviteter, som de ikke står bag.

Seneste eksempel er kampene i Zinjibar i provinsen Abyan, der af internationale medier er blevet rapporteret som al-Qaedas forsøg på at overtage kontrol med byen. Men det er ikke al-Qaeda, som står bag, derimod andre militante islamiske grupper. Netop den forvirring i kombination med USA's seneste initiativ, droneangreb, kan betyde øget op- bakning til al-Qaeda i Yemen. Under CIA's nye program for droneangreb kan ukendte personer, som følger et vist handlingsmønster, angribes. Militante islamister og al-Qaeda-medlemmer kan være svære at skelne fra hinanden, så førstnævnte kan også blive mål. Militante islamiske grupper har hidtil taget afstand fra alQaedas kamp, fordi der ikke i Yemen, som i Irak og Afghanistan, er en direkte vestlig militær indblanding. Med en optrapning af droneangreb vil det argument forsvinde, og al-Qaeda vil få lettere ved at rekruttere. Dertil kommer, at tidligere droneangreb ofte har haft civile dødsofre, hvilket har skabt oprør fra stammer med blandt andet angreb på strøm- og olieforsyning til hovedstaden.

\section{Svag stat - stærkt samfund}

Det har længe været frygtet, at Yemen ville ende som en fejlslagen stat, og landet er kun rykket op på Foreign Policy's Failed State Index i mange år. Hvad der ofte bliver overset i debatten, er spørgsmålet om, hvorvidt man i Yemen overhovedet kan tale om en stat i klassisk forstand. Staten har aldrig haft fuld kontrol over territoriet, endsige voldsmonopol. Bevæger man sig uden for trekanten af de tre største byer, Sana'a, Aden og Taiz, er statens reelle magt begrænset og stammerne er de egentlige magtudøvere. At Saleh har kunnet opretholde 
statsmagten så længe, skyldes, at han har været en dygtig strateg og fra starten været sig bevidst, at han ikke med brug af magt kunne vinde over stammerne.

Så i stedet for at forsøge at bekæmpe disse eller begrænse deres indflydelse, en fejltagelse der kostede tidligere præsident Ibrahim alHamdi livet i 1977, er Saleh gået en kompliceret balancegang. Han har lokket mange magtfulde sheiker til Sana'a med løfter om et moderne liv og økonomisk gevinst. Samtidig har han indført et statsautoriseret system for udnævnelse af sheiker.

De nye, og mindre magtfulde, sheiker er blevet placeret i landsbyerne, hvor de med økonomisk støtte fra regimet har kunnet sørge for deres stammer og vinde disses tillid. De gamle sheiker er stadig officielle sheiker, men deres reelle indflydelse og magt er blevet stækket af Saleh. Den igangværende konflikt er derfor ikke bare en kamp om statsmagten, men også en magtkamp om indflydelse over Yemens substatslige aktører, hvor de gamle sheiker forsøger at generobre deres stammers loyalitet og positionere disse over for andre stammer.

Statens svaghed over for stammerne og det stærke yemenitiske civilsamfund er dog ikke entydigt negativ. Det kan meget vel være den faktor, der gør, at Yemen ikke havner i en langtrukken og altødelæggende borgerkrig. De yemenitiske stammer har en lang tradition for forhand- ling og løsning af konflikter. Konflikter involverer brug af vold og væbnede sammenst $ø$ d er ofte intense, men kortvarige. Volden tjener mere til at etablere parternes position, inden forhandling kan påbegyndes, end til udslettelse af modstandere.

At stammerne indtil for meget nylig har indordnet sig under den fredelige strategi, som oppositionen og de unge demonstranter havde udstukket for oprøret, vidner om deres store vilje til politisk forhandling fremfor brug af vold. Både stammerne, den politisk etablerede opposition i Yemen og den del af hæren, der står på de unge demonstranters side, er sig bevidst, at vold meget hurtig kan eskalere med den store forekomst og spredning af våben $\mathrm{i}$ landet. Netop fordi ingen aktører er andre tydeligt overlegne i militær styrke, fungerer våbnene som en præventiv faktor, der begrænser gevinsten ved at anvende dem.

\section{Usikker fremtid}

I denne flerdimensionelle konflikt med dybe historiske rødder og international indblanding har det arabiske forår og de unge demonstranter således primært spillet en symbolsk rolle. Med tegn på fragmentering $\mathrm{i}$ koalitionen og de mere magtfulde aktørers forsøg på at positionere sig til magten, ville det være fristende at konkludere, at de unge demonstranter har udspillet deres rolle. Men 
det er for tidligt at fraskrive dem indflydelse på fremtiden. For samtidig med at de har banet vejen for nye organisationsformer og politisk aktivitet for den yemenitiske befolkning, betyder den forværrede $ø$ konomiske situation, at befolkningen ikke bare kan vende tilbage til livet før revolutionen. Det yemenitiske folk har ikke noget at gå hjem til, før vand, mad, elektricitet, benzin og gas atter er tilgængeligt. Den kritiske økonomiske situation har medført nye protester overalt i landet, som vil fortsætte uanset udfaldet af den politiske magtkamp.

I skrivende stund er alle kort spillet ud i Yemen, og uanset om det går mod en borgerkrig, eller koalitionen formår at besejre Salehs søn og nevøer samt overvinde sine interne uenigheder, så er fremtiden usikker.

Statssammenbrud er ikke usandsynligt, og selv om det vil betyde fragmentering af Yemen, vil det ikke nødvendigvis udvikle sig til et nyt Somalia eller Afghanistan.
Stammerne og andre substatslige aktører er vant til at regere på egen hånd, og det vil de fortsætte med blot helt uden indblanding fra en statsmagt, der ofte har skabt mere konflikt end sammenhængskraft i landet.

Skulle landet formå at komme samlet gennem krisen med et nyt politisk styre i Sana'a, vil det kræve en stor regional og international indsats at genoprette landets økonomi og modvirke det økonomiske kollaps og den deraf følgende humanitære krise, der lige nu udgør den største trussel mod demokrati, fred og sikkerhed i fremtidens Yemen.

Siris Hartkorn er BA i freds- og konfliktvidenskab fra Lunds Universitet med speciale $i$ sikkerhedspolitik $i$ Yemen. Har fra 2009 arbejdet $i$ Somalia, Yemen og Kenya, fra januar 2011 bosat $i$ Yemens hovedstad Sana'a som uafhengig analytiker og konsulent for internationale organisationer og virksomheder. 